\title{
Facial Mask Formulation Enriched with Moringa Leaves (Moringa oleifera) Extract and Their Activity as Antioxidants and Antibacterials
}

\author{
Hendrawati*, Yulyani Nur Azizah, Niah Kusuma Hapsari, \\ Department of Chemistry, Science and Technology Faculty, Syarif Hidayatullah Islamic State University, South \\ Tangerang, 15412, Indonesia \\ *Corresponding author: hendrawati@uinjkt.ac.id
}

Received: August 2020; Revision: August 2020; Accepted: February 2021; Available online: February 2021

\begin{abstract}
Moringa leaves (Moringa oleifera) are useful for skin health as an additional ingredient for cosmetics, such as facial mask. This study aims to determine the optimum formula of Moringa leaves extract in powder mask, evaluate its activity as an antioxidant and antibacterial, while also ascertaining its characteristics, based on the quality requirements of SNI 16-6070-1999 and SNI 16-4399-1996 for cosmetics and skin moisturizers, respectively. Facial mask formula was made through various concentrations of Moringa leaves methanol extract $12.5 \%, 17.5 \%, 25 \%$, and $35 \%$, with its optimum formulation determined by panelists' preference level, based on organoleptic test results. Furthermore, the antioxidant activity was carried out, using the 1,1-diphenyl-2picrylhydrazil (DPPH) method, while that of the antibacterial towards Staphylococcus aureus bacteria was performed, through the use of the diffusion technique, with the active compound also being analyzed, using GCMS (Gas Chromatography-Mass Spectrophotometry). The results however, showed that the antioxidant and antibacterial activities in the facial mask formula were lower than when in their extract form. The facial mask formula with the addition of $35 \%$ Moringa leaves extract (F4), had the highest inhibitory value of $66,04 \%$, while the antibacterial activity against $\mathrm{S}$. aureus occured at concentrations $\geq 0.125 \mathrm{~g} / \mathrm{mL}$. Also, the result of GC-MS analysis of Moringa leaves extract, showed quinic (peak 7, $\mathrm{Rt}=21,165$ minutes) and linoleic acid as the highest peak (peak 12, Rt $=29,439$ minutes). Based on panelists' preference level, the result of Anova and Duncan Test analysis showed that the most optimum facial mask product was with $17.5 \%$ Moringa leaves extract (F2), with a score of 3.29. Therefore, all characterization of mask formula with $12.5 \%, 17.5 \%, 25 \%$, and $35 \%$ additional amount of Moringa leaves extract, have met up with the requirements for SNI 16-6070-1999 and SNI 16-43801996 criterias, together with the $\mathrm{pH}$ value of $5.45-6.02$, specific gravity $1 \mathrm{~g} / \mathrm{mL}$, emulsion stability 96.57 $97.05 \%$, and negative microbial contamination.
\end{abstract}

Keywords: Antibacterial, antioxidant, facial mask, Moringa oleifera.

DOI: https://doi.org/10.15408/jkv.v6i2.16982

\section{INTRODUCTION}

In recent years, the trends of health awareness through the use of natural materials and additives on both beauty products and personal care, has been on the rise. Plant extracts have been observed to be rich sources of bioactive compounds, which provide nutrients for healthy skins (Amberg \& Fogarassy, 2019; Ribeiro et al., 2015). As compared with synthetic cosmetic products (Davis \& Stout, 1971), herbal superficials are mild, biodegradable, and possess low toxicity profile (Chanchal \& Swarnlata, 2008; Joshi \& Pawar, 2015). Furthermore, facial masks are a part of beauty products which are easily applied, instantly moisturizes, removes sebum, and rejuvenates the skin. Based on its form, there are several types of facial masks, such as gel, emulsion, sheet, and paste (Nilforoushzadeh et al., 2018).

Also, Moringa is a type of plant, which is used in facial care products. Moreover, it is known to be the world's most valuable multipurpose and miracle trees (Small, 2012). All parts of this plant are used for various purposes, such as food, medicine, and cosmetics, with the seeds also being used as water purifiers (Hendrawati et al., 2015). Also, there are at least 300 diseases, which are cured by consuming the basic ingredients of Moringa plants, rich in protein, vitamins (A, B, C), and minerals (Offor \& Ehiri, 2014). The minerals 
contained in Moringa are also known as an exfoliator in body cream scrubs (Hendrawati $e t$ al., 2019).

Due to significant decrease in erythema content, the exploration and utilization of Moringa leaf extract as a supplement in facial masks, is potentially safe for topical applications (Ali et al., 2013). Furthermore, the total phenolic antioxidant present in Moringa leaves reduces free-radical damage, and inhibit inflammation, which is $111 \%$ higher than its flowers (Ali et al., 2013; Sankhalkar \& Vernekar, 2016). Also, phytochemical test result of Moringa leaves indicated the presence of phenolic contents, such as tannins, alkaloids, flavonoids, saponin, anthraquinones, steroids and triterpenoids, which are all acting as antioxidant (Kasolo et al., 2010).

Moreover, previous studies showed the antibacterial activity of peel-off gel (Moringa leaf ethanol extract) against Staphylococcus aureus bacteria, through the use of well method which did not reveal any inhibitory power in less than 9\% product (Tunas, Edy, \& Siampa, 2019). This was due to the viscosity of peel-off gel inhibiting the activity of the ethanol extract, while not affecting its antioxidant process (Hasanah, Yusriadi, \& Khumaidi, 2017). Therefore, powdered masks containing Moringa leaf extracts were formulated, using powder basis to optimize both antioxidant and antibacterial activities, which then complies with the SNI cosmetic standards.

\section{MATERIALS AND METHODS}

\section{Materials and Instruments}

The Moringa leaves were obtained from Bekasi, and determined at the Biology Centre for the Field of Botany, and the Centre for Biological Research - LIPI Cibinong. The main component used for the mask were Moringa leaves methanol extract, zinc oxide, yam and rice flour, with rose oil. Also, the Staphylococcus aureus bacteria from the Qlab Pharmacy Laboratory, Pancasila University, was tested with the Mueller Hinton Agar (MHA) media, with the antioxidant being analyzed, using DPPH (2,2-diphenyl-1pycrilhidrazyl, Aldrich). Furthermore, the instruments used in this study included UVVis spectrophotometers (Thermo Scientific), GC-MS (Shimadzu), glassware (pyrex), ovens (memmert), microtubes, rotary evaporators (Heidolph-Lborota 4000), analytical scales (Ohaus), $\mathrm{pH}$ meter (Mettler Toledo), incubator (memmert), mask container, blender, filter paper, ose, autoclave, mortar, and stamper.

\section{Moringa Leaves Extract Preparation}

The Moringa leaves were cleaned by using running water, dried in the air, and mashed to produce its powder. The powder (42 grams) was extracted by using methanol (900 $\mathrm{mL}$ ), stirred with a magnetic stirrer for 30 mins, then left for 24 hours at room temperature. The methanol extract was then filtered and evaporated with a rotary evaporator (Nurindo et al., 2013).

\section{Mask Formulation}

As regards mask preparation, Moringa leaves extract was added to rice flour and rose oil according to previous research (Ismiyati \& Trilestrasi, 2014), with determined concentrations (Table 1). Due to the possession of low water content, the powder preparations were chosen, making them difficult to be grown by microbes. Rice flour has the ability to adsorb dirt, cool the skin and cause excess oil on the face, while the rose oil provides a refreshing scent to the skin.

Table 1. Formulation of moringa leaves mask

\begin{tabular}{|c|c|c|c|c|c|c|c|}
\hline \multirow[b]{2}{*}{ Ingredients } & \multicolumn{7}{|c|}{ Groups } \\
\hline & $\begin{array}{l}\text { Positive } \\
\text { control }\end{array}$ & $\begin{array}{l}\text { Negative } \\
\text { control }\end{array}$ & Fo & F1 & F2 & F3 & F4 \\
\hline $\mathrm{ZnO}$ & $0.150 \mathrm{~g}$ & & - & - & - & - & - \\
\hline Yam flour & - & $0.150 \mathrm{~g}$ & - & - & - & - & - \\
\hline $\begin{array}{l}\text { Moringa leaves } \\
\text { extract }\end{array}$ & - & - & - & $0.625 \mathrm{~g}$ & $0.875 \mathrm{~g}$ & $1.250 \mathrm{~g}$ & $1.750 \mathrm{~g}$ \\
\hline Rice flour & $4.850 \mathrm{~g}$ & $4.850 \mathrm{~g}$ & $5.000 \mathrm{~g}$ & $4.375 \mathrm{~g}$ & $4.125 \mathrm{~g}$ & $3.750 \mathrm{~g}$ & $3.250 \mathrm{~g}$ \\
\hline Rose oil & 3 drops & 3 drops & 3 drops & 3 drops & 3 drops & 3 drops & 3 drops \\
\hline
\end{tabular}

Note: F4 $=35 \%$ moringa leave extract addition, $\mathrm{F} 3=25 \%$ moringa leave extract addition, $\mathrm{F} 2=17.5 \%$ moringa leave extract addition, $\mathrm{F} 1=12.5 \%$ moringa leave extract addition, $\mathrm{F} 0=$ without extract addition. 


\section{Organoleptic and Mask Characterization}

The organoleptic characterization was tested on 45 untrained panelists, as they were told to assess product samples by filling out the forms provided, including colour, aroma, texture, homogenity, and overall commodity acceptance. They also assessed the level of likes and dislikes for powdered mask products, through the use of a five point likert scale (1-5) (BSN, 2006).

Other parameters including $\mathrm{pH}$ value, emulsion stability, density, and total microbial contamination were analyzed. The analysis referred to the SNI (Indonesian National Standard) 16-4399-1996 and 16-6070-1999, which concerns the quality of sunscreen and mask preparations carried out on facial products, respectively. However, both results were processed, using the SPSS application and the ANOVA one-way test method. Other significant results obtained, were further analyzed by the Duncan test.

\section{pH Value}

The metre was standardized by dipping the electrode into a standard $\mathrm{pH}$ of 6.86 , and washed with distilled water. $1 \mathrm{~g}$ sample of moringa leaves mask diluted with distilled water (1:10) was then stirred until evenly distributed. Therefore, the $\mathrm{pH}$ metre electrode was dipped into the diluted sample, and the number recorded was the $\mathrm{pH}$ value.

\section{Stability of Emulsion}

A total of $5 \mathrm{~g}$ emulsion in a petri dish was stored in an oven at $45 \mathrm{oC}$ for 1 hour, then placed in a cooler below $0 \mathrm{oC}$ for 1 hour afterwards. The plate containing the sample was reheated for 1 hour at $45 \mathrm{oC}$, as observations were made on the possibility of separating water from the emulsion. However, the separated water was absorbed by the filter paper, as the stability of emulsion was calculated, based on the percentage of separate phases to the whole sample.

Stabilization of emulsion $=\frac{M R}{M T E} \times 100$

Note,

$\mathrm{MR}=$ (mass of emulsion after reheating + petri disk) - petri disk,

$\mathrm{MTE}=($ mass of total emulsion + petri disk $)-$ petri disk.

\section{Specific Gravity}

Clean and dry microtubes were weighed scaleusing an analytical scale. A total of $1 \mathrm{~mL}$ distilled water was filled into the microtube through the use of a micro pipette, and placed in a cooler until the temperature was $25^{\circ} \mathrm{C}$. The microtube was then left to stand at room temperature, and weighed. Similar step was carried out for the remaining sample. The analysis referred to the SNI 16-4399-1996, concerning the quality of sunscreen preparations.

Specific gravity $(\mathrm{g} / \mathrm{mL})=\frac{(b-a)}{(c-a)}$

Note,

$\mathrm{a}=$ mass of microtube,

$\mathrm{b}=$ mass of microtube + sample,

$\mathrm{c}=$ mass of microtube+aquadest.

\section{Analysis of Total Microbial Contamination}

The sample was diluted with sterile diluent to $10^{-3}$, then homogenized. Moreover, 1 $\mathrm{mL}$ of each sample dilution was pipetted into a sterile petri dish, as $12-15 \mathrm{~mL}$ of liquid Plate Count Agar (PCA) media was poured. The petri dish was shaked slowly until the sample was well blended. The mixture was allowed to solidify, then placed invertedly in an incubator $(35 \pm 10 \mathrm{oC})$ for 48 hours. The number of microbial population in $1 \mathrm{~g}$ or $1 \mathrm{~mL}$ of the sample was calculated by multiplying the average value of colonies on a plate with the dilution factor. Also, the analysis referred to SNI 16-6070-1999, concerning the quality of mask preparations.

\section{Antioxidant Activity Test}

The Moringa leaves extract $(2 \mathrm{~mL})$ in a methanol solvent was placed into a test tube, as $2 \mathrm{~mL}$ of DPPH was added to it. The mixture was vortexed until homogenity was attained, then incubated at room temperature for 30 mins, in a dark room. Furthermore, absorption was measured at $516 \mathrm{~nm}$ wavelength, on a UVVis spectrophotometer. Also, similar method was used to examine the antioxidant activity of formulated facial mask (F0, F1, F2, F3 and $\mathrm{F} 4$ ), which was diluted with aquadest in a ratio of 1:2. Ascorbic acid was also tested as a positive control, with concentrations of 0.25 $\mu \mathrm{g} / \mathrm{mL}, 0.5 \mu \mathrm{g} / \mathrm{mL}, 1 \mu \mathrm{g} / \mathrm{mL}, 2 \mu \mathrm{g} / \mathrm{mL}$, and 4 $\mu \mathrm{g} / \mathrm{mL}$. 


\section{Antibacterial Activity Test}

The medium was carried out by dissolving $5.8 \mathrm{~g}$ of Mueller Hinton Agar (MHA) in $100 \mathrm{~mL}$ of boiling distilled water, which was stirred continuously until it dissolved completely. The flask covered with cotton and wrapped in gauze was then sterilized in an autoclave, at $121^{\circ} \mathrm{C}$ for 15 mins. However, in the manufacture of microbial suspensions, bacterial colonies were suspended into a clindamycin solution of $2 \mu \mathrm{g}$, and homogenized. The turbidity was further measured up to $25 \%$, with the help of a UVVis spectrophotometer.

Furthermore, a total of $25 \mathrm{~mL}$ of MHA medium was placed in a petri dish, as $2 \mathrm{~mL}$ of a homogeneous bacterial suspension was added to it, then allowed to condense. The Moringa leaf extracts and standards were further placed into each disc, and incubated at $37{ }^{\circ} \mathrm{C}$ for $18-24$ hours. Variations of the Moringa leaves extract concentration used were $1 \mathrm{~g} / \mathrm{mL}, 0.5 \mathrm{~g} / \mathrm{mL}, 0.25 \mathrm{~g} / \mathrm{mL}$, and 0.125 $\mathrm{g} / \mathrm{mL}$. Therefore, the resultant inhibition zone formed was observed and measured in diameter, as similar processes were carried out for the formulated facial masks (F0, F1, F2, $\mathrm{F} 3$, and F4), with a concentration of $1 \mathrm{~g} / \mathrm{mL}$ in distilled aquades.

\section{Determination of Moringa Leaves Extract Active Compound using GC-MS}

The active compounds of Moringa leaves extract were identified, using GC-MS with methanol as a solvent. The column type, length, and diameter used in this process were the Rtx-5MS phase capillaries, $25 \mathrm{~m}$, and 0.25 $\mathrm{mm}$, respectively. Also, the carrier gas used was helium, with an Injection room and pyrolysis temperature of $250{ }^{\circ} \mathrm{C}$. The column temperature of $60^{\circ} \mathrm{C}$, flow rate of $1 \mathrm{~mL} / \mathrm{min}$, injection volume of $1 \mu \mathrm{L}$, pressure of $57.4 \mathrm{kPa}$, and the degree of ion source at $230^{\circ} \mathrm{C}$, were also used. However, the number of compounds contained in the extract were indicated by the value of peaks on the chromatogram, while the type of compound used in the similarity method was interpreted in the GC-MS database.

\section{RESULTS AND DISCUSSION}

In this study, the results observed from the Botanical Sector of the Biology Research
Center-LIPI, Cibinong, indicated that the test plants obtained from Bekasi were indeed Moringa oleifera species, from inthe Moringaceae family. The Moringa leaves powder obtained during the preparation process was $63 \mathrm{~g}$, after drying from $250 \mathrm{~g}$ of fresh samples. Furthermore, extraction was carried out by maceration method, with the use of methanol as a solvent (Rahmahani et al., 2013). The maceration method was discovered to be suitable for extracting active substances, which were heat-resistant chemical components. Also, the green extract of Moringa leaves were obtained after being concentrated by a vacuum rotary evaporator, with a yield value of $10.72 \%$. The phytochemical screening results further showed that Moringa leaves contained alkaloids, flavonoids, phenolics, tannins, triterpenoids, and steroids (Table 2). This result was consistent with previous studies, except the negative reaction of saponins (Kasolo et al., 2010).

Due to the unstable formation of foam after the addition of $\mathrm{HCl} 2 \mathrm{~N}$, the saponin test showed a negative result. The foam observed in this result showed the presence of glycosides, which had the ability to form froth in water being hydrolyzed into glucose and other compounds (Pardede, Manjang, \& Efdi, 2013). Also, saponin was usually discovered in all plants with high concentrations in certain parts, which are being influenced by varieties and growth stages. Furthermore, the mask formulations were divided into 5 groups, namely F0, F1, F2, F3, and F4, with the addition of Moringa leaves extract by $0 \%$, $12.5 \%, 17.5 \%, 25 \%$, and $35 \%$, respectively. The basic ingredients of the mask formula was rice flour, which had the ability to adsorb impurities, cool the skin, and removes excess oil on the face. Additionally, rice flour tightens and reduce pores on the face, when applied as a mask. Another type of ingredient used was rose oil, which gives a refreshing aroma to the skin, and also serves as an antibacterial effect against $S$. aureus (Ulusoy, Bosgelmez-Tmaz, $\&$ Secilmis-Canbay, 2009). Other functions of rose oil includes anti-inflammatory, antioxidant, skin moisturizer, mind calming, pores tightening, and skin elasticity restoration. Also, the powdered mask was applied, through the use of rose water as an evaporating solvent. 
Table 2. Phytochemical screening result of Moringa leaves extract

\begin{tabular}{lllc}
\hline Compound groups & \multicolumn{1}{c}{ Reactants } & \multicolumn{1}{c}{ Observation } & Results \\
\hline Alkaloids & Wagner & Brown precipitate are formed & + \\
Flavonoids & Conc. $\mathrm{HCl}+\mathrm{Mg}$ powder & Brownish green to yellowish green & + \\
Phenolic & $\mathrm{FeCl}_{3} 1 \%$ & Brownish green to blackish blue & + \\
Tannin & Aquades panas $+\mathrm{FeCl}_{3} 1 \%$ & Greenish brown prep. & + \\
Triterpenoid and & Lieberman Burchard & Brownish green to purplish red & + \\
Steroids & Heated, shaked $+\mathrm{HCl} 2 \mathrm{~N}$ & No foam & - \\
Saponin & Note,$(+)$ compound groups are present, $(-)$ compound groups are absent.
\end{tabular}

Note, (+) compound groups are present, (-) compound groups are absent.

Table 3. Observation result of Moringa leaves mask

\begin{tabular}{ccccc}
\hline Sample & Color & Texture & Aroma & Homogeneity \\
\hline F0 & White & Soft & Typical flour & Sufficient \\
F1 & Light yellow & Soft & Typical of Moring leaves & Sufficient \\
F2 & Light yellow & Soft & Typical of Moring leaves & Sufficient \\
F3 & Brownish yellow & Soft & Typical of Moring leaves & Sufficient \\
F4 & Brownish yellow & Soft & Typical of Moring leaves & Sufficient \\
\hline
\end{tabular}

Moreover, Moringa leaves mask products have a light yellow to brownish yellow colour (Figure 1). Due to the greater concentration of Moringa content in the mask formula, the increasing colour intensity was also observed as the characteristic aroma of the leaves, which appeared to be getting stronger. Therefore, the resulting powdered mask products have sufficient homogenity and fine texture, as described in Table 3.
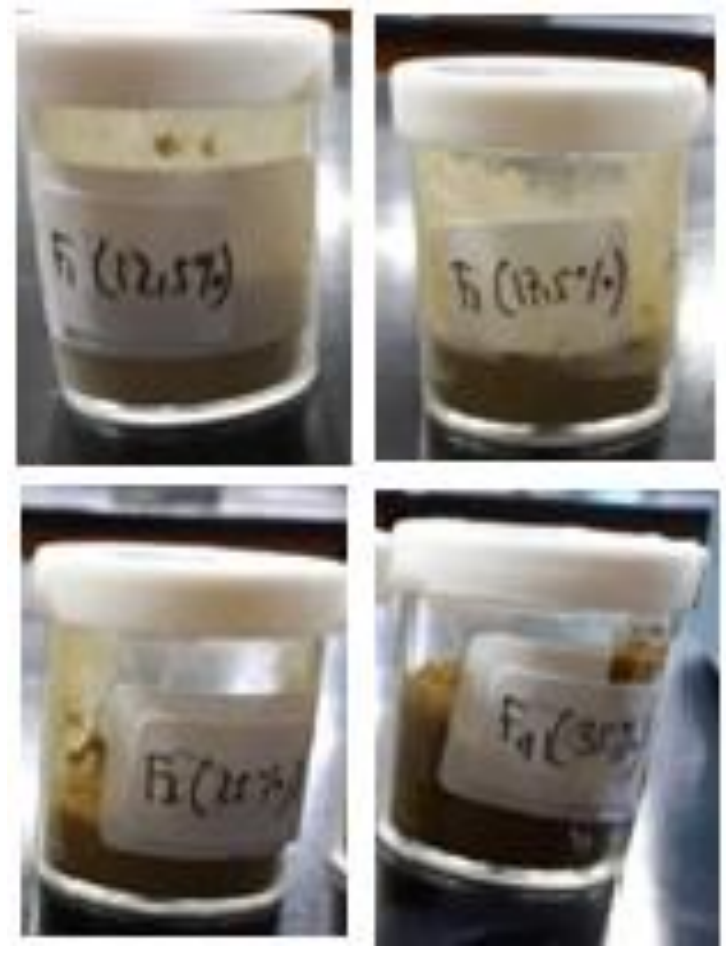

Figure 1. Powder mask product

\section{Organoleptic and Mask Characterization Based on SNI}

The organoleptic test involved 45 panelists, in order to provide an assessment of the like and dislike levels for powdered mask products. The parameters tested in organoleptics were texture, colour, aroma, homogenity, and general preferences, as shown in Table 4. Also, the results of Anova analysis in supplementary data showed that there was no significant difference in the level of texture, preference, and homogenity of each mask formula. This further showed that the addition of Moringa leaf extract in the mask formula does not affect the panelists' preference. However, the colour and aroma showed a significant difference in the addition of Moringa leaves extract to the panelists' preference. Based on the results of Duncan's further test on the level of colour and aroma preference, it was observed that F0, F1, and F2 were preferred because of their lighter colouration and less pungent scent.

The acidity level observed from the $\mathrm{pH}$ value is a very important factor in cosmetic products. According to SNI 16-4399-1996, the required $\mathrm{pH}$ value of cosmetic products is in the range of $4.5-8.0$. Also, cosmetic products having a very high/low $\mathrm{pH}$ value, are very likely to cause skin irritation. The $\mathrm{pH}$ analysis results in this study had values ranging from 5.45-6.02, which appeared to still be well within the range of quality requirement. As a 
result of the acidic content, the outcome of Anova and Duncan test analysis showed a significant difference in the mask products, with or without the addition of the Moringa leaves. The longer the storage time, the more acidic the preparation of facial masks tends to become, due to the interaction of $\mathrm{CO}_{2}$ with water, and flour phase (Wang, Li, Copeland, Niu , \& Wang, 2015). Furthermore, specific gravity measurements were carried out, in order to determine the level of product stability. It was observed that the incorrect ratio between dispersing and dispersed phases, led to lower value of emulsion product stability. Also, the weight constituent confirmed the effectiveness of the ingredients used in the product formula. According to SNI 16-4399-1996, the required specific gravity value of a product should range between 0.95 to $1.05 \mathrm{~g} \mathrm{/} \mathrm{mL}$, in order to achieve stability. However, the results of this study showed that the specific gravity value was well within the range of $1 \mathrm{~g} / \mathrm{mL}$, which signifies good stability of the mask products. Also, the results of statistical tests with one-way Anova, further showed that the masks did not show any significant differences, as the probability value was $0.781(\mathrm{P}>0.05)$. Therefore, this confirmed that the addition of Moringa leaves extract does not affect the specific gravity of a mask product.

Furthermore, the emulsion contained in the material does not have the tendency to form a separate layer, change the colour, and also possess a permanent consistency in the product, clearly indicating a balance in the result of this study. Also, the stability of the emulsion on the mask is influenced by mechanical factors, temperature, and the formation processes (Maphosa \& Jideani, 2018). The results of the mask analysis test further showed that the average value of the emulsion stability was within the range of 96.57 - 97.05\%. However, these results indicated that the sample hardly showed any phase separation, which in turn confirmed that the mask products had a stable emulsion. Also, the total microbial contamination is part of the parameters guaranteed for the protection of the consumers' product use, in order to avoid the negative effects of microbes, which arises from the usage of the commodity. Furthermore, microbial contamination causes deterioration of the emulsion product quality, which is characterized by the shrinkage of commodity weight, phase separation, and unpleasant odours over time (Neza \& Centini, 2016). The results also showed that the masks produced were safe to use, because the total microbes were still below the microbial limits required.

Moreover, the masks produced have $\mathrm{pH}$, specific gravity, emulsion stability, and total microbial contamination, which are in the range of the SNI standard values 16-43991996 and 16-6070-1999, concerning the quality of sunscreen and mask preparations, respectively. The observations of the result further indicated that the panelist preference level on the addition of Moringa leaves extract as a mask active agent, was acceptable. Based on the organoleptic test results, the best mask product was obtained with the addition of 17.5\% Moringa leaves extract (F2). Also, antioxidant activity of Moringa leaves extract and mask formula were tested by DPPH (2,2diphenyl-1-pycrilhidrazyl) radical absorption method. The ability to neutralize free radicals was reflected in the absorption-reduction process, at a wavelength of $516 \mathrm{~nm}$. Furthermore, Moringa leaves contain several flavonoids, such as kaempferol, quercetin, rhamnetin, quercetagetin and proanthocyanidin. The antioxidant effect of flavonoid compounds was due to the capture of free radicals, via hydrogen proton donors from hydroxyl groups (Seyoum et al., 2006).

Moringa leaves extract have the potential as an antioxidant, through the $\mathrm{IC}_{50}$ measured below in Table 5 , as it was also observed to be lower than the results of previous studies (Seyoum et al., 2006; Ulusoy et al., 2009). Also, mask formula preparations were thought to reduce the antioxidant activity of Moringa leaves extract. Previous research had shown that the inhibition of Moringa leaf methanol extract was $90.59 \pm 0.39 \%$ (Fitriana et al., 2016), while the mask formulated ranged between $28.9-66.04 \%$. Therefore, the best facial mask formulation with the highest antioxidant activity is F4, with the addition of $35 \%$ Moringa leaf extract. 
Table 4. Overall mask quality

\begin{tabular}{|c|c|c|c|c|c|c|c|}
\hline \multirow{2}{*}{ No. } & \multirow{2}{*}{ Parameters } & \multicolumn{5}{|c|}{ Treatment } & \multirow{2}{*}{ SNI } \\
\hline & & F0 & F1 & F2 & F3 & F4 & \\
\hline 1 & Texture & 3.22 & 3.47 & 3.56 & 3.42 & 3.49 & \\
\hline 2 & Color & 3.91 & 3.60 & 3.47 & 3.20 & 3.07 & \\
\hline 3 & Aroma & 3.71 & 2.89 & 3.09 & 2.84 & 2.84 & \\
\hline 4 & Homogeneity & 3.22 & 3.69 & 3.71 & 3.67 & 3.60 & \\
\hline 5 & General preferred & 3.49 & 3.27 & 3.29 & 3.13 & 2.98 & \\
\hline 6 & $\mathrm{pH}$ value & 6.02 & 5.86 & 5.72 & 5.50 & 5.45 & $4.5-8$ \\
\hline 7 & Specific gravity $(\mathrm{g} / \mathrm{mL})$ & 1.03 & 1.01 & 1.05 & 1.03 & 1.02 & $0.95-1.05$ \\
\hline 8 & Emulsion stability (\%) & 96.57 & 96.87 & 97.04 & 97.05 & 96.72 & \\
\hline 9 & $\begin{array}{l}\text { Microbial contamination } \\
\text { (colony/ gram) }\end{array}$ & none & none & none & None & None & $\operatorname{Max} 10^{3}$ \\
\hline
\end{tabular}

Table 5. Moringa leaves extract and mask formula antioxidant activities

\begin{tabular}{lcc}
\hline Sample & $\begin{array}{c}\text { Inhibition } \\
(\boldsymbol{\%})\end{array}$ & $\mathbf{I C}_{\mathbf{5 0}}(\boldsymbol{\mu g} / \mathbf{m l})$ \\
\hline F0 & $6.50 \pm 1.00$ & \\
F1 & $28.91 \pm 1.75$ & \\
F2 & $51.44 \pm 1.42$ & \\
F3 & $60.84 \pm 1.18$ & \\
F4 & $66.04 \pm 0.07$ & \\
Ascorbic acid & $96.24 \pm 0.01$ & $2.17 \pm 0.01$ \\
Moringa leave & $90.59 \pm 0.39$ & $56.34 \pm 0.13$ \\
extract & & \\
\hline
\end{tabular}

In the antibacterial activity test, the disc diffusion method was used with clindamycin as a positive control, with sterile distilled water being negative. Due to the diffusion of a clear area surrounding the disc, the effectiveness of the antibacterial agents was shown by the inhibition zones. However, antibiotics as positive controls produced inhibition zones of $30.90 \mathrm{~mm}$, while distilled water as that of the negative produced regions of $6 \mathrm{~mm}$. Based on the inhibition zone category, each concentration of Moringa leaves methanol extract was categorized as very strong (Ramadhani \& Ermawati, 2020). The higher the concentration of Moringa leaves methanol extract, the more the increase of average inhibition diameter formed around the disc paper. In accordance with Table 6, Moringa leaves extract has inhibitory activity against $S$. aureus, at concentrations $\geq 0.125 \mathrm{~g} / \mathrm{mL}$.

In comparison to the extract, the activity on the formula mask of moringa leaves tend to be smaller (Table 7), although all equations showed antibacterial potentials. Also, antibacterial activity was influenced by several factors, including the content of compounds, extract concentration \& diffusion, power, and the types of bacteria inhibited (Maliana et al., 2013).

Table 6. Inhibitoty diameter of Moringa leaves methanol extract

\begin{tabular}{lc}
\hline $\begin{array}{c}\text { Concentration } \\
(\mathbf{g} / \mathbf{m L})\end{array}$ & $\begin{array}{c}\text { Inhibitory diameter } \\
(\mathbf{m m})\end{array}$ \\
\hline positive control & $30.90 \pm 0.42$ \\
0.125 & $11.45 \pm 0.21$ \\
0.250 & $12.40 \pm 0.28$ \\
0.500 & $14.55 \pm 1.06$ \\
1.000 & $17.00 \pm 2.12$ \\
negative control & $6.00 \pm 0.00$ \\
\hline Notes, positive control= & antibiotic, negative \\
control= distilled water &
\end{tabular}

Table 7. Inhibitoty diameter of Moringa leaves facial mask

\begin{tabular}{lc}
\hline Formulation & Inhibitory diameter $(\mathbf{m m})$ \\
\hline positive & $24.00 \pm 0.00$ \\
control & $12.10 \pm 0.14$ \\
F4 & $11.00 \pm 0.00$ \\
F3 & $10.05 \pm 0.07$ \\
F2 & $10.00 \pm 0.00$ \\
F1 & $9.40 \pm 0.56$ \\
F0 & $6.00 \pm 0.00$ \\
negative & \\
control &
\end{tabular}

Notes, positive control $=3 \%$ of $\mathrm{ZnO}$, negative control= yam flour

\section{Analysis of Chemical Component of Moringa Leaves Methanol Extract with GC- MS}

The Gas Chromatography-Mass Spectrophotometry (GC-MS) analysis aimed to determine the active compounds contained in the Moringa leaves extract. 


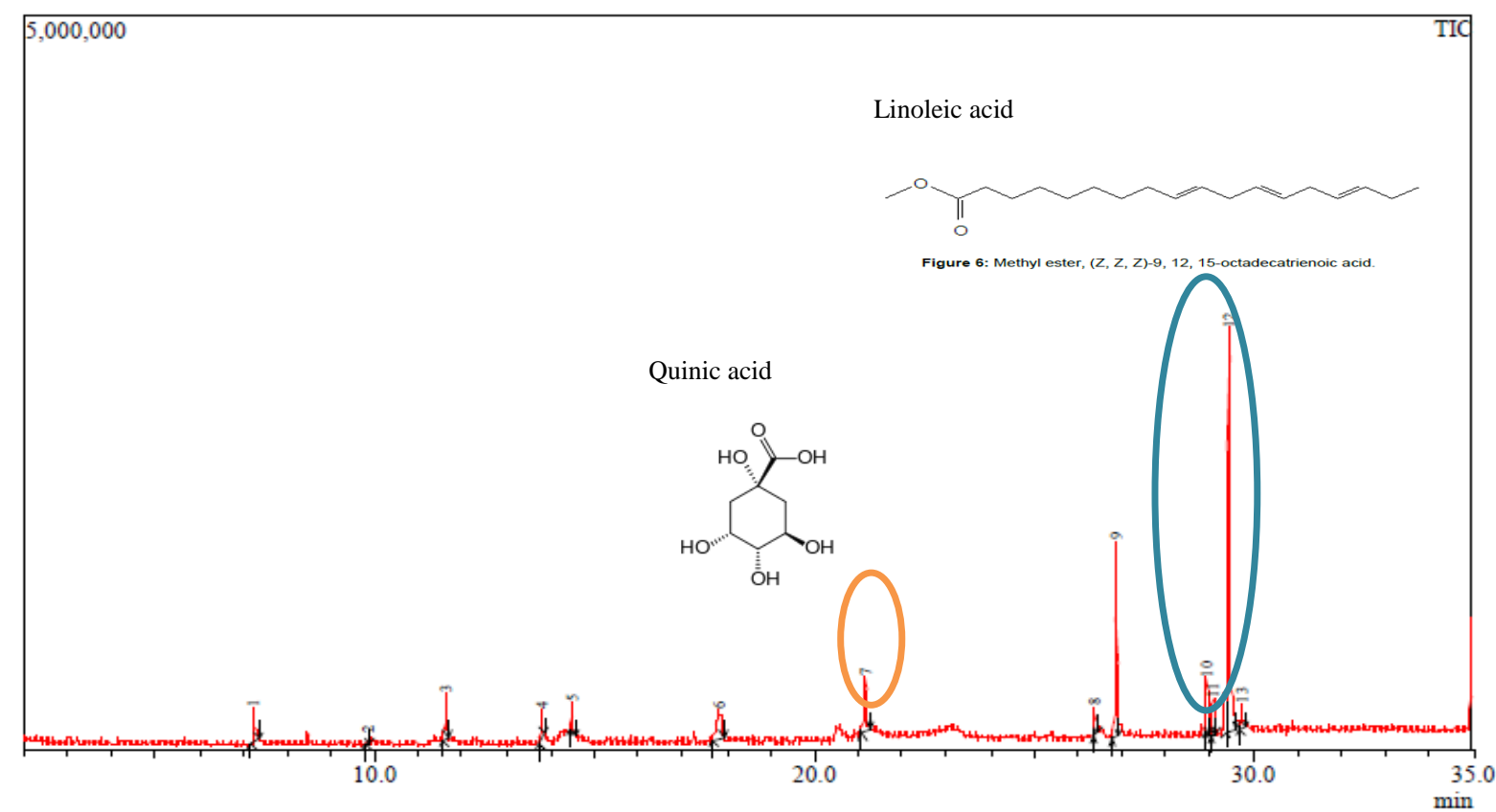

Figure 2. Chromatogram results from the separation of Moringa leaves extract

The chromatogram results in Figure 2 showed that peak 7 had a retention time (Rt) of 21.165 mins with a level of $7.42 \%$, which indicated a quinic acid with molecular weight $(\mathrm{m} / \mathrm{z})$ 192. Furthermore, the peaks that occurred in the fragmentation of these compounds were 186, 156, 138, 112, 100, 84, 71,60 , and $43(\mathrm{~m} / \mathrm{z})$. Peak 12 being the highest of all, had a retention time (Rt) of 29.439 mins with a level of $41.81 \%$ which indicated a linoleic acid with molecular weight $(\mathrm{m} / \mathrm{z}) 278$. Also, the peaks that occurred in the fragmentation of these compounds were 264, 249, 222, 209, 191, 164, 149, 135, 121, 108, 95, 79, 67, 55, and $41(\mathrm{~m} / \mathrm{z})$. Moreover, linoleic acid was discovered to have the highest value of fatty acids in dried Moringa leaves, which in turn acted as antibacterial agents (Lee, Kim et al., 2017; Moyo et al., 2011). Therefore, it was observed that both quinic and linoleic acids functioned as antioxidant and antibacterial agents (Gopalakrishnan et al., 2016; Iqbal \& Bhanger, 2006; Karra et al., 2020).

\section{CONCLUSION}

The antioxidant activity of Moringa leaves methanol extract produced $\mathrm{IC}_{50}$ of 56.34 $\mu \mathrm{g} / \mathrm{mL}$, while the antibacterial event of extract against $S$. aureus occurred at concentrations $\geq$ $0.125 \mathrm{~g} / \mathrm{mL}$. Furthermore, the facial mask formula with the addition of $35 \%$ Moringa leaves extract had the highest inhibitory value of $66.04 \%$, compared to other formulations without further additions. All characterization of mask formulation enriched with Moringa leaves extract $(12.5 \%, 17.5 \%, 25 \%$, and $35 \%)$, achieved the quality requirements of SNI 166070-1999 and SNI 16-4380-1996, with a $\mathrm{pH}$ value of $5.45-6.02$, specific gravity of 1 $\mathrm{g} / \mathrm{mL}$, emulsion stability of $96.57-97.05 \%$, and negative microbial contamination. Also, the most optimum facial mask formula was with the addition of $17.5 \%$ Moringa leaf extract, which had the highest general preference level (F2). Therefore, the active compounds identified through the use of Gas Chromatography-Mass Spectrophotometry (GC-MS) showed the presence of quinic and linoleic acids, which were functioning as antioxidant and antibacterial agents.

\section{REFERENCES}

Ali A, Akhtar N, Mumtaz AM, Khan MS, Iqbal MF, Zaidi SS. 2013. In vivo skin irritation potential of a cream containing Moringa oleifera leaf extract. African Journal of Pharmacy and Pharmacology. 7(6): 289293.

Amberg N, Fogarassy C. 2019. Green customer behavior in the cosmetics market. Resources. 8(137): 1-19. 
Chanchal D, Swarnlata S. 2008. Novel approaches in herbal cosmetics. Journal of Cosmetic Dermatology. 7: 89-95.

Davis WW, Stout TR. 1971. Disc plate method of microbiological antibiotic assay II. novel procedure offering improved accuracy. Applied Microbiology. 22(4): 666-670.

Fitriana WD, Ersam T, Shimizu K, Fatmawati S. 2016. Antioxidant activity of Moringa oleifera extracts. Indones. J. Chem. 3: 297301.

Gopalakrishnan L, Doriya K, Kumar DS. 2016. Moringa oleifera: a review on nutritive importance and its medicinal application. Food Science and Human Wellness. 5(2): 49-56.

Hasanah U, Yusriadi, Khumaidi A. 2017. Formulation gel of ethanolic's extract of the leaves of Moringa oleifera Lam as an antioxidant. Journal of Natural Science. 6(1): 46-57.

Hendrawati, Rohaeti E, Effendi H, Darusman LK. 2015. Characterization of physico-chemical properties of nano-sized Moringa oleifera seed powder and its application as natural coagulant in water purification process. Journal of Environment and Earth Science. 5(21): 19-26.

Hendrawati, Savitri AK, Fitriyati N, Mustika AA. 2019. Formulation of the body scrub cream containing moringa seed powder (Moringa oleifera) and its examination dermal acute irritation. International Journal of Geomate. 17(62): 244-249.

Iqbal S, Bhanger MI. 2006. Effect of season and production location on antioxidant activity of Moringa oleifera leaves grown in Pakistan. Journal of Food Composition and Analysis. 19: 544-551.

Ismiyati N, Trilestrasi. 2014. Formulation development of avocado leaf water extract (Persea americana Mill) mask as antibacterial Staphylococcus aureus for acne treatment. Pharmaciana. 4(1): 45-52.

Joshi LS, Pawar HA. 2015. Herbal cosmetics and cosmoceuticals: an overview. Natural Products Chemistry \& Research. 3(2): 1-8.

Karra S, Sebii H, Jardak M, Bouaziz MA, Attia H, Blecker C, Besbes S. 2020. Male date palm flowers: valuable nutritional food ingredients and alternative antioxidant source and antimicrobial agent. South African Journal of Botany. 131: 181-187.

Kasolo JN, Bimenya GS, Ojok L, Ochieng J, Ogwal-okeng JW. 2010. Phytochemicals and uses of Moringa oleifera leaves in Ugandan rural communities. Journal of Medicinal Plants Research. 4(9): 753-757.

Lee J, Kim Y, Gyu J, Lee J. 2017. Supercritical fluid extracts of Moringa oleifera and their unsaturated fatty acid component inhibit biofilm formation by Staphylococcus aureus. Food Control. 80: 74-82.

Maliana Y, Khotimah S, Diba F. 2013. Aktivitas antibakteri kulit Garcinia mangostana Linn. terhadap pertumbuhan Flavobacterium dan Enterobacter dari Coptotermes curvignathus Holmgren. Jurnal Protobiont. 2(1): 7-11.

Maphosa Y, Jideani VA. 2018. Factors affecting the stability of emulsions stabilised by biopolymers in S. karakus (Ed.). Science and Technology Behind Nanoemulsions. 65-81.

Moyo B, Masika PJ, Hugo A, Muchenje V. 2011. Nutritional characterization of moringa (Moringa oleifera Lam.) leaves. African Journal of Biotechnology. 10(60): 1292512933.

Neza E, Centini M. 2016. Microbiologically contaminated and over-preserved cosmetic product according Rapex 2008-2014. Cosmetics. 3(3): 1-11.

Nilforoushzadeh MA, Amirkhani MA, Zarrintaj P, Moghaddam AS, Mehrabi T, Alavi S, Sisakht MM. 2018. Skin care and rejuvenation by cosmeceutical facial mask. Journal of Cosmetic Dermatology. 17: 693702.

Nurindo F, Indra MR, Lyrawati D. 2013. Ekstrak metanol daun kelor mempengaruhi ekspresi p53 mukosa kolon tikus yang diinduksi DMBA. Jurnal Kedokteran Brawijaya. 27(4): 207-211.

Offor I, Ehiri R. 2014. Proximate nutritional analysis and heavy metal composition of dried Moringa oleifera leaves from Oshiri Onicha L.G.A., Ebonyi State, Nigeria. IOSR Journal of Environment Science, Toxicology and Food Technology. 1(1): 57-62.

Pardede A, Manjang Y, Efdi M. 2013. Phytochemical screenings methanol extract 
from bark of manggis (Garcinia cymosa). Media Sains. 6(2): 60-66.

Rahmahani FN, Indra MR, Lyrawati D. 2013. Methanol extract Moringa oleifera leaves affects p53 expression in Rattus novergicus colon mucosa induced by DMBA. Jurnal Kedokteran Brawijaya. 27(4): 207-211.

Ramadhani CI, Ermawati DE. 2020. Formulation of anti-acne gel of Moringa oleifera L. ethanolic extract and bacteriostatic test on Staphylococcus epidermidis. Majalah Farmaseutik. 16(2): 154-162.

Ribeiro AS, Estanqueiro M, Oleivera MB, Lobo JM. 2015. Main benefits and applicability of plants extracts in skin care products. Cosmetic. 2: 48-65.

Sankhalkar S, Vernekar V. 2016. Quantitative and qualitative analysis of phenolic and flavonoid content in Moringa oleifera Lam and Ocimum tenuiflorum L. Pharmacognosy Reseacrh. 8(1): 16-21.
Seyoum A, Asres K, El-fiky FK. 2006. Structure radical scavenging activity relationship of flavonoids. Phytochemistry. 67: 2058-2070.

Small E. 2012. Top 100 Exotic Food Plants. London(UK): Taylor \& Francis Group.

Tunas TH, Edy HJ, Siampa JP. 2019. Efek antibakteri ekstrak etanol daun kelor (Moringa oleifera Lam.) dan sediaan masker gel peel-off ekstrak etanol daun kelor (Moringa oleifera Lam.). Jurnal Mipa. 8(3): 112-115.

Ulusoy S, Bosgelmez-Tmaz G, Secilmis-Canbay H. 2009. Tocopherol, carotene, phenolic contents and antibacterial properties of rose essential oil, hydrosol and absolute. Current Microbiology. 59: 554-558.

Wang S, Li C, Copeland L, Niu Q, Wang S. 2015. Starch retrogradation: a comprehensive review. Comprehensive Review in Food Science and Food Safety. 14: 568-585. 